\title{
Macroeconomic Energy Efficiency Portfolio Model of Indonesia
}

\author{
Fathul Nugroho', Noor Syaifudin $2,3, *$ \\ ${ }^{1}$ The Future Institute, Dukuh Patra V No.48, Kuningan, Jakarta, Indonesia \\ ${ }^{2} U W A$ Business School, Business School Building, Crawley Campus The University of Western \\ Australia 35 Stirling Highway Crawley WA 6009 Perth, Australia \\ ${ }^{3}$ Fiscal Policy Agency, Ministry of Finance of Republic of Indonesia, \\ Notohamiprodjo Building, 1st Floor, Jl. Wahidin No 1, Senen, Jakarta, 10710, Indonesia
}

\begin{abstract}
There has been a decreasing trend in Indonesia's energy efficiency. Indonesia's energy efficiency decreased at the annual rate of $1.4 \%$ over the last 27 years from \$246.23 per million Btus in 1980 to $\$ 165.51$ per million Btus in 2007. In the absence of initiatives by the government as well as the citizens to improve energy efficiency, Indonesia's energy efficiency will decline gradually in the next 25 years by around $45.51 \%$. This study attempts to address this policy problem by providing policy recommendations based on in-depth analysis and evaluation of the policy alternatives.
\end{abstract}

Keywords: Energy Efficiency; Macroeconomic Model; Energy Portfolio; Renewable Energy

\section{Introduction}

The steadily increasing price of energy has resulted in higher energy costs to industry for production and simultaneously a larger portion of household expenditures going on energy. The growing energy demand and prices also affect the State Budget (APBN) contributing to ever higher energy subsidies. Further, the high dependency on fossil fuel energy contributes to slowing down efforts to reduce greenhouse gas (GHG) emissions. Thus, biomass utilization by conversion from $\mathrm{WtE}$ is an alternative energy source that allows reductions in GHG emissions. As the fourth most populous country in the world, Indonesia consumes an enormous amount of energy, especially fossil fuels. Even though Indonesia is a major oil producer, the present production is 
not enough to cover daily domestic consumption, which is estimated to be at 1.2 million barrels per day. As such, it becomes a major problem for the energy sector and the economy of Indonesia. The high level of fossil fuels consumption is due to the inefficient usage of energy in transportation, industrial, power generation, and residential sectors. In the last ten years, these sectors consumed approximately $70 \%$ of Indonesia's total energy consumption (Ministry of Energy and Mineral Resources, 2005). Thus, inefficient usage of energy will result in lower energy efficiency.

\begin{tabular}{|ll|}
\hline & \multicolumn{1}{c|}{ Nomenclature } \\
APBN & $\begin{array}{l}\text { Anggaran Pendapatan dan } \\
\text { Belanja Negara/ State Budget }\end{array}$ \\
GHG & Green House Gas \\
GDP & Gross Domestic Product \\
MoE & Ministry of Environment \\
MEMR & Ministry of Energy and \\
Mineral Resources & Energy Information \\
EIA & Administration \\
&
\end{tabular}

The impact of low energy efficiency is macroeconomic inefficiency. Theoretically, the expression of energy efficiency is the ratio of the economic output of an economy over its total energy supply. In other words, the energy efficiency of economic production means how efficiently each unit of primary energy is being used for producing a dollar of gross domestic products (GDP). The most popular measure of energy efficiency is using the energy intensity indicator since energy efficiency simply means an inverse form of energy intensity. Therefore, Indonesia's energy efficiency can be easily predicted using World Energy Intensity data, which is obtained from Energy Information Administration (EIA) annual reports.

\section{Objectives}

This study aims to present the overview of Indonesia's current energy demand and energy efficiency as well as its trend in the future. By presenting such an up-to-date analysis of energy demand and efficiency, it is expected that the policy makers will have a clear perspective on current trends in Indonesia's energy sector. Provide an analysis of the contribution of renewable energy to improving Indonesia's energy efficiency. As noted above, this study aims to analyze whether renewable energy will improve Indonesia's energy efficiency as the literature reviews have suggested. This analysis is expected to convince the client that the policy recommendation is supported by a comprehensive analysis.

\section{Method}

Primary data obtained from Ministry of Energy and Mineral Resources database, World Development Indicators (WDI) provided online by the World Bank, Energy Information Administration (EIA), International Energy Agency (IEA), and literature reviews of recent publications. In addition, the energy efficiency based on WDI data, energy efficiency based on EIA data, energy efficiency, and capital stock are obtained through some calculations using Microsoft Excel and Efficiency Measurement System (EMS) programs. This study mainly uses regression analysis to calculate energy efficiency and estimate the impact of Indonesia's energy efficiency and GDP.

\section{Energy Efficiency Issue in Indonesia}

In the ten years after the Asian Financial Crisis, Indonesia has enjoyed modest economic growth. The GDP growth rates were about $5 \%$ to $6 \%$ year on year. However, the economic 
growth is mainly driven by domestic consumption instead of from exports. In 2008, the trade balance was US\$ 31.76 billion, which comprises of US $\$ 118$ billion of exports and US\$ 86.24 billion of imports. In addition, the exports commodities are mainly comprised of primary commodities such as crude palm oil, crude oil, and LNG that have low value added.

Meanwhile, Indonesia imports a large volume of oil from the global market, and as a result, this affected much of government's budget and trade balance. Given this situation where economic structure comprises with energy intensive industry and high dependence on fossil fuel import, Indonesia faces problems on its energy efficiency. The IEA data shows that Indonesia's energy efficiency has been steadily decreasing since 1980 and it has not shown any significant improvement until today. Indonesia Energy efficiency is decreased by $1.40 \%$ per annum (Fig. 1.). That is, in the last 27 years Indonesia's energy efficiency has been declining from $\$ 246.23$ per million Btus in 1980 to $\$ 165.51$ per million Btus in 2007, it means that if there is no real action from the government and the citizens in converting and conserving energy, Indonesia energy efficiency will decline gradually in the next 25 years by $45.51 \%$ between the year 2008 and 2033 .

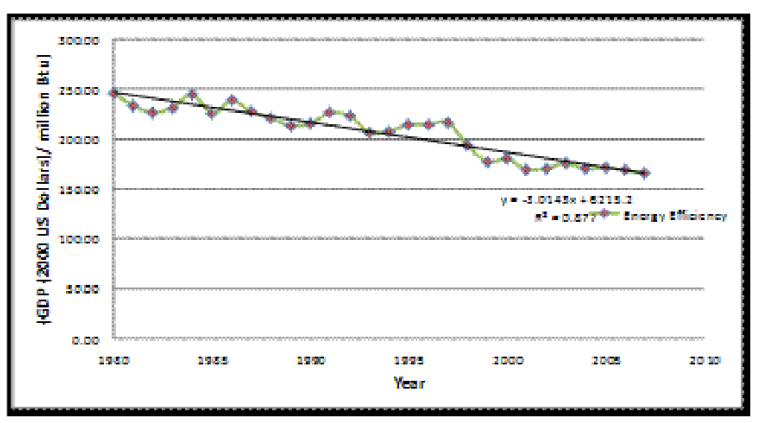

Fig. 1. Indonesia Energy Efficiency GDP per unit of energy $1980-2007$ (2000 Dollars per million Btus)
The low level of energy efficiency will have a great impact on the energy sector and the economy of Indonesia. The impacts will vary from energy supply crisis, increasing the budget for oil subsidies, low economic productivity, low value-added commodities, to low competitiveness of Indonesian economy among other countries in the world. The World Competitiveness Yearbook 2008 placed the competitiveness of Indonesian economy at 52nd among 55 countries in the world (Institute for Management Development, 2008); which is far below neighbouring countries Singapore and Malaysia, which are ranked at 3 rd and 8th.

Factors causing decreasing trend in Indonesia's energy efficiency

There are several explanations to address this policy question. First, the decline in energy efficiency has been driven by the increasing demand for fossil fuels. As the national economy was growing at a relatively high rate before the Asian Financial Crisis and modest rates after the crisis, Indonesia experienced a higher per capita income that resulted in shifting consumer preferences and increasing demand for energy-intensive consumer products such as automobiles, air-conditioners, water heaters, etc. Consequently, the total amount of energy used has increased in the last two decades along with the increases of energy intensive products and sectors of the economy. In addition, the increasing number of Indonesia's population at the rate of $\mathbf{1 . 2}$ $\%$ per year has also contributed to low energy efficiency. Energy consumption per capita is rising as the population increases, which also means higher fuels consumption for transportation, industrial machinery, and electricity power plants for more people in the 
future. As commonly known, Indonesia relies much on fossil fuels exports and the current oil production is at a decreasing rate; while liquefied natural gas (LNG) production remains constant. As a result, the high number of oil import will reduce the total GDP. Moreover, the use of fossil fuels has a negative relationship with energy efficiency. Fossil fuels, especially oil and coal have low thermal efficiency compared to natural gas and renewable energy. The combustions of oil and coal will not only result in the thermal heat but also the high residue of carbon dioxide, which means that not all inputs of this energy would be converted to useful work. Consequently, the use of oil and coal will result in low energy efficiency.

Second, the nation's economic structure is relying much on energy intensive industries, and it contributed to the decreasing rate of Indonesia energy efficiency. As noted above, the major contributor to Indonesia's economic growth is the high household consumption, not the export. Indonesia's main export commodities are oil and gas, palm oil, and other primary goods that have low value added in the international market. In addition, the majority of industries are comprising with low technology intensive and energy inefficient industries. However, this is a normal phenomenon; Nielsen (1993) argues that when a developing nation shifts to become an industrializing country, it may repeat the experience of developed nations with a phase of decreasing energy efficiency. There is, however, developing countries also have the opportunity to achieve the same level of energy efficiency in developed economies if they employ the most energy efficient technologies.

\section{Energy Efficiency Studies}

A study by Wei (2007) applied CobbDouglas production function to analyze the impact of energy efficiency gains in economic output. The study counted energy, labor, and capital stock as inputs of the production function and found that energy the energy efficiency gains always lead to higher output. Thus, the impact of energy efficiency on total output in the long term almost doubles than that in the short term. Hu and Kao (2007) also mentioned that energy, labor, and capital stock are the key inputs to produce the economic output.

Data envelopment analysis (DEA) is employed to measure an efficiency frontier for Indonesian economy in each year. The macroeconomic energy efficiency is to seek how far the economy of Indonesia is from its efficiency frontier in that year. Currently, the DEA method has been widely used for measuring energy efficiency among scholars. A key benefit of DEA method over other models is that this method takes into account the dynamic efficiency of multiple inputs and multiple outputs. The DEA method was introduced by Charnes et al. (1978). This method is the best fit to measure the energy efficiency frontier of an economy by combining multiple inputs and outputs. This type of linear programming allows the user to choose between input orientation and output orientation methods. Input orientation method calculates energy efficiency by combining the multiple inputs while holding constant the multiple outputs. Meanwhile, the output orientation computes the variables by combining the multiple outputs while holding constant the multiple inputs.

There are some scholars who have been using the DEA methods in their study on energy efficiencies such as Boyd and Pang in Charnes et al. (1978) who studied the linkage between energy efficiency and total factor productivity. Chien and $\mathrm{Hu}$ (2007) employed the DEA to measure macroeconomic productivity. 
Zhou and Ang (2008) employed the DEA method to calculate energy efficiency by considering the undesirable output of the economy. That is, they take into account $\mathrm{CO} 2$ emissions as the undesirable output within the framework of the production function. They also employed several DEA type linear programming models for calculating macroeconomic energy efficiency. In addition, their models treat different energy sources as different inputs so that changes in energy mix could be accounted for evaluating energy efficiency.

Abulfotuh (2008) argues that if there is a change in energy sources portfolio by increasing the share of renewable energy, the environmental risk caused by fossil fuels emission can be reduced. Chien and $\mathrm{Hu}$ (2007) have found a direct linkage between renewable energy and energy efficiency. They verified that an increase in the percentage of renewable energy among total primary energy supply (TPES) improves energy efficiency. It is worth noting that increasing the input of renewable energy increases energy efficiency. Domac et al. (2005) propose that renewable energy is a key driver for energy development and that renewable energy project will create employment and reduce energy imports, and as a result, the overall energy efficiency will be improved. Furthermore, Chien and $\mathrm{Hu}$ (2007) argue that increasing the share of renewable energy among total energy supply will significantly improve a nation's energy efficiency. They suggest that the implementation of renewable energy should be supported by integrated renewable energy and energy efficiency policies.

\section{Macroeconomic Energy Efficiency Model}

The analysis in this section uses energy efficiency data resulted from DEA computation to verify the contribution of renewable energy to improving Indonesia energy efficiency. Based on the theory, renewable energy is expected to improve nation's energy efficiency. The analysis employs logistic regression analysis model to measure the relationship of renewable energy and energy efficiency. All data in this section are obtained from WDI online database. The regression equations are as follow:

First model: $L n E E=\beta O+\beta 1 \operatorname{Ln} G D P+$ $\beta_{2} \operatorname{Ln} C S+\beta 3 L n L F+\beta 4 F F C+$ $\beta 5$ Ln REC

Second model: $\operatorname{Ln} E E=\beta O+\beta 1 \operatorname{Ln} G D P+$ $\beta 2 L n C S+\beta 3 L n L F+\beta 4 F F C+$ $\beta 5 \mathrm{Ln} R E C+\beta 6 \mathrm{Ln} C \mathrm{CO}$

Third model: $L n E E=\beta O+\beta 1 \operatorname{Ln} G D P+$ $\beta 2 L n C S+\beta 3 L n L F+\beta 4 F F C+$ $\beta 5 \operatorname{Ln} R E C+\beta 6 \operatorname{Ln} E C$

Where EE is energy efficiency, GDP gross domestic products, CS capital stock, LF labor force, FFC fossil fuel consumption, REC renewable energy consumption, EC electricity consumption, and $\mathrm{CO}_{2}$ carbon dioxide emissions.

\section{Results and discussion}

The regression analysis using energy efficiency method employs eight variables, which are (1) GDP gross domestic products; (2) $\boldsymbol{C S}$ capital stock; (3) $\boldsymbol{L F}$ labor force; (4) $\boldsymbol{F F C}$ fossil fuel consumption; (5) REC renewable energy consumption; (6) $\boldsymbol{C E}$ clean energy consumption; (7) $\boldsymbol{E C}$ electricity consumption, and (8) $\mathrm{CO} 2$ carbon dioxide emissions. GDP, labor force, and capital stock variables are included as controlling variables in the three models. The energy inputs have used the data from WDI, that is, fossil fuel, renewable energy, and clean energy. By the definition of WDI, renewable is combustible renewables and waste energy, while clean energy is renewable 
Table 1. The regression analysis using energy efficiency

Dependent Variable: Energy Efficiency (DEA)

\begin{tabular}{|c|c|c|c|}
\hline Regressor & Model 1 & Model 2 & Model 3 \\
\hline Intercept & $-67.573^{* *}(24.919)$ & $-51.035^{*}(28.719)$ & $-34.391(24.045)$ \\
\hline Ln GDP & $-0.245(0.367)$ & $0.06(0.366)$ & $-0.788 * *(0.363)$ \\
\hline Ln LF (labor force) & $2.619^{* *}(0.969)$ & $1.861(1.172)$ & $0.985(0.996)$ \\
\hline Ln CS (capital stock) & $0.631^{*}(0.332)$ & $0.468(0.359)$ & $0.613^{* *}(0.282)$ \\
\hline Ln FFC (fossil fuels consumption) & $-0.734(0.568)$ & $-0.349(0.658)$ & $-0.972(0.490)^{*}$ \\
\hline Ln RE (renewable energy consumption) & $1.177^{* *}(0.481)$ & $0.982 *(0.508)$ & $1.112^{* *}(0.411)$ \\
\hline Ln EC (electricity consumption) & & & $0.757^{* * *}(0.258)$ \\
\hline Ln $\mathrm{CO}_{2}$ (carbon dioxide emissions) & & $-0.172(0.151)$ & \\
\hline \multicolumn{4}{|l|}{ Summary Statistics } \\
\hline Adjusted R2 & 0.255 & 0.266 & 0.460 \\
\hline F-statistic & $2.715^{* *}$ & $2.509^{*}$ & $4 \cdot 554^{* * *}$ \\
\hline DW-statistic & 1.672 & 1.617 & 2.326 \\
\hline
\end{tabular}

energy that has low emissions.

In the equation for model 2, $\mathrm{CO} 2$ emissions variable is included. Zhou and Ang (2008) argue that $\mathrm{CO} 2$ emissions should be included in measuring energy efficiency because $\mathrm{CO} 2$ emissions are the undesirable output of economic production. However, for Model 3, $\mathrm{CO} 2$ emissions variable is excluded from the equation. Even though Zhou and Ang (2008) argue that $\mathrm{CO} 2$ emissions should take into account in energy efficiency measurement as the undesirable output of production, I argue that $\mathrm{CO}_{2}$ emissions are the residue of primary energy combustions that should not be taken into account because they are already part of the primary energy. Therefore, $\mathrm{CO} 2$ emissions should not be taken into account as input in the production function. In this model, however, I included electricity consumption into the equation, since electricity is the main source of power for many industries and commercial businesses.

The regression findings of Model 1 show that renewable energy does significantly affect energy efficiency. The coefficient of renewable energy is $\mathbf{1 . 1 1 7}$ and statistically significant at 5\% level. The interpretation is that renewable energy does improve energy efficiency by 1.117 percent in every $1 \%$ increase the share of renewable energy by holding other variables constant. For Model 1 , the variables of the labor force and capital stock are significant at 5\% and $10 \%$ respectively.

For Model 2, all variables are insignificant at all levels except renewable energy variable. In Model 2 the renewable energy coefficient (o.982) is significant at $10 \%$ level of significance. The inclusion of $\mathrm{CO}_{2}$ emissions as a variable in the regression equation is likely as the cause of the insignificance of some variables. As I argued, the $\mathrm{CO}_{2}$ emissions should not be included into the equation because they already account as the part of fossil fuels.

For Model 3, the variable of GDP, capital stock, fossil fuels, renewable energy, and electricity are statistically significant at $5 \%, 5 \%, 10 \%, 5 \%$, and $1 \%$ levels respectively. The third model has confirmed that by substituting total 
energy supply with renewable energy, macroeconomic energy efficiency will be improved. In other words, increasing the supply of fossil fuels energy will cause a decrease in energy efficiency. Therefore, it is important for Indonesia to change its energy portfolio by adopting more renewable energy. The regression results tell us that by increasing the share of renewable energy by 1 percent, the energy efficiency will be improved by 1.112 percent, holding other variables constant.

\section{Energy efficiency development}

\section{Transport}

The transportation sector is the major factor that caused the diminishing rate of a nation's energy efficiency. This sector is the biggest consumer of oil fuels and the amount of oil consumed has increased very rapidly every year. The data from ESDM (2007) shows that in 2001, transportation consumed about 22.94 thousand kiloliters of gasoline, which is $43.12 \%$ from the total gasoline consumption. In 2003 and 2005, the consumptions rose rapidly to about 27 and 30 thousand kiloliters or $46.80 \%$ and $48.28 \%$ from total national consumptions. This is surprising since the government had boosted up the gasoline price in that time, but the consumptions of gasoline for transportation remained high.

Total energy consumption in the transportation sector has grown rapidly at a rate of 6.3 percent per year over the past two decades. The rapid growth rate of transportation energy consumption is driven by the road sub-sector, and it has contributed to about 87 percent of the incremental growth. Gasoline consumption for private cars and motorcycles has increased about twofold, as well as the buses and trucks. In the future, energy demand for the transportation sector is projected to grow at 3.9 percent annually. Roads sub-sector will remain as the major contributor to the rapid increase of energy consumption in the transportation sector, accounting for 87 percent of the total transport energy demand by 2030.

The increasing demand for energy in the transportation sector has contributed to the lowering the air quality in big cities in Indonesia. In addition, the widely used type of gasoline is the gasoline with the high lead additive. In order to improve Indonesia air quality, MoE has set an ambitious target to reduce the CO2 emission by $17 \%$ by 2025 . One of the programs is called the Blue-Sky program introduced in 1996. The program comprises of reduction in the use of highleaded gasoline and promotes the use of catalytic converters for motor vehicles. The other transportation subsectors, marine and air transportations, are important transportation modes to connecting the citizens from different islands. Oil demand for these sub-sectors is projected to grow at an annual rate 1 percent and 5.3 percent respectively. The increasing demand in the air subsector has mainly been driven by the increasing number of passengers due to lower airfares provided by domestic and foreign airlines.

Three factors contribute to the increasing demand for oil products in the transportation sector. First, the supply and quality of public transportation facilities are low. On the one hand, the supply of mass rapid transportation such as buses and trains are very low. With the rapid growing of population and high rate of urbanization, the current facilities do not meet the high demand for public transportations. The number of public transportations is only 57,000 or $1.5 \%$ from the total number of motor vehicles. Thus, the ratio of public transportations and the population is quite low, only 
0.22 percent. A study from the World Bank shows that the conditions of public transportation are very poor, about $78 \%$ of it was overloaded (Taylor et al., 2008). As a result, the public has to choose private transportations over public buses or trains.

On the other hand, the quality of public transportations is also low. Most of the buses and other types of public transportation are too old and not wellmaintained. The maintenance costs for motor vehicles in Indonesia are very high because the prices of the vehicles' spare parts are also high since Indonesia has to import most of the spare parts from overseas. As a result, most of the engines of the public transportation vehicles are not fuel-efficient.

Second, the number of motor vehicles has been growing at a phenomenal rate. Between 1999 and 2005, the number of motor vehicles has doubled from around 18 million to 39 million vehicles. The rapid growth of the number of motor vehicles is driven by low supply and quality of public transportations. The public has chosen private transportation over public transportation because most of the public transportations were overloaded. In addition, as the per capita income is projected to grow the number of vehicles will also be growing from 3.4 million units in 2002 to 13.9 million units in 2030. As a result, from this trend, the gasoline consumption of this sector will increase by about 2,000 kilolitres each year.

Third, the quality and supply of transportation infrastructure are low. The number of motor vehicles has been growing at a faster rate rather than the development of road infrastructure. Consequently, high traffic congestions appear everywhere. In addition, the quality of the infrastructure is very low; most of the roads were damaged, and as a result, the travel time is longer than normal. The combination of these two factors has also contributed to the high oil consumption in the transportation sector.

From the analysis above, it is clear that transportation is the most energyintensive sector. However, this sector has a big chance for energy efficiency

Table 2. Motor vehicles figure in Indonesia 1987 - 2005.

\begin{tabular}{|c|c|c|c|c|c|}
\hline Year & $\begin{array}{c}\text { Passenger } \\
\text { Car }\end{array}$ & Buses & Trucks & $\begin{array}{l}\text { Motor } \\
\text { Cycles }\end{array}$ & Total \\
\hline 1987 & 1170103 & 303378 & 953694 & 5554305 & 7981480 \\
\hline 1988 & 1073106 & 385731 & 892651 & 5419531 & 7771019 \\
\hline 1989 & 1182253 & 434903 & 952391 & 5722291 & 8291838 \\
\hline 1990 & 1313210 & 468550 & 1024296 & 6082966 & 8889022 \\
\hline 1991 & 1494607 & 504720 & 1087940 & 6494871 & 9582138 \\
\hline 1992 & 1590750 & 539943 & 1126262 & 6941000 & 10197955 \\
\hline 1993 & 1700454 & 568490 & 1160539 & 7355114 & 10784597 \\
\hline 1994 & 1890340 & 651608 & 1251986 & 8134903 & 11928837 \\
\hline 1995 & 2107299 & 688525 & 1336177 & 9076831 & 13208832 \\
\hline 1996 & 2409088 & 595419 & 1434783 & 10090805 & 14530095 \\
\hline 1997 & 2639523 & 611402 & 1548397 & 11735797 & 16535119 \\
\hline 1998 & 2769375 & 626680 & 1586721 & 12628991 & 17611767 \\
\hline 1999*) & 2897803 & 644667 & 1628531 & 13053148 & 18224149 \\
\hline 2000 & 3038913 & 666280 & 1707134 & 13563017 & 18975344 \\
\hline 2001 & 3261807 & 687770 & 1759547 & 15492148 & 21201272 \\
\hline 2002 & 3403433 & 714222 & 1865398 & 17002140 & 22985193 \\
\hline 2003 & 3885228 & 798079 & 2047022 & 19976376 & 26706705 \\
\hline 2004 & 4464281 & 933199 & 2315779 & 23055834 & 30769093 \\
\hline 2005 & 5494034 & 1184918 & 2920828 & 28556498 & 38156278 \\
\hline
\end{tabular}


improvement. Thus, in order to improve energy efficiency in the transportation sector, the government should provide mass rapid transportation to the public and followed by a limitation to the number of private cars to encourage the public to switch from private cars to public transportation and reduce the number of private cars on the road. However, the government should provide good quality and integrated mass rapid transportation; otherwise, the people will still prefer to travel by private cars.

\section{Industry}

In the last two decades, Indonesia's industry sector has been dominated by energy-intensive industries. Like the transportation sector, this sector is also contributing to the decline of Indonesia energy efficiency. There are some key energy intensive industries namely steel, low-quality ceramics, tyres, cement, and glass industries. These sectors' energy intensities are $700 \mathrm{kWh} / \mathrm{t}, 16.6 \mathrm{GJ} / \mathrm{t}$, $8100 \mathrm{kcal} / \mathrm{kg}, 800 \mathrm{kcal} / \mathrm{kg}$ clinker, 12.4 $\mathrm{GJ} / \mathrm{t}$ respectively. Compare to other countries, Indonesia's energy intensity in the industry sector is among the most energy inefficient countries. For instance, iron and steel industries give a clear comparison between Indonesia and other APEC countries. Energy intensity of Indonesia's iron and steel manufacturing is $17 \mathrm{GJ} /$ tonne, while best practices in other APEC countries vary from $6-34 \mathrm{GJ} /$ tonne, it is just about average. However, energy intensities for other industries such as cement and glass are below the best practice levels. These examples provide an illustration that industry sector comprises of energy intensive industries. However, it also provides a picture that industry sector has great potential to achieve a higher energy efficiency.

The industrial sector is projected to consume more energy in the future; because its growth rate is estimated to be at 4 percent per annum, which is lower compared to growth in the last 20 years. The slower growth rate of energy demand in the industry sector is due to the shift in Indonesia's industry structure, which has been moved from energy intensive industries to more energyefficient industries. There have been structural changes in some domestic industries. They have shifted from high-energy intensive to more energyefficient industries. Higher foreign direct investments, especially from Japan, have driven some industries to move into high-tech industries such as electronics

Table 3. Key energyintensive industries

\begin{tabular}{|c|c|c|c|}
\hline & Indonesia & Comparable SE Asian & Best practice \\
\hline Sector & Energy intensity & Energy intensity & Energy intensity \\
\hline Steel: Electric arc fumaces & $700 \mathrm{kWh} / \mathrm{t}$ & $604 \mathrm{kWh} / \mathrm{t}$ (India) & $500 \mathrm{kWh} / \mathrm{t}$ (Japan) \\
\hline Low-quality ceramics & $16.6 \mathrm{GJ} / \mathrm{t}$ & $12.9 \mathrm{GJ} / \mathrm{t}$ (Niehnam) & \\
\hline Tyres & $8100 \mathrm{kcal} / \mathrm{kg}$ & $7000 \mathrm{kcal} / \mathrm{kg}$ (Thailand) & \\
\hline Cement & $800 \mathrm{kcal} / \mathrm{kg}$ dinker & & $773 \mathrm{kcal} / \mathrm{kg}$ clinker \\
\hline Glass & $12.4 \mathrm{GJ} / \mathrm{ton}$ & & $10.2 \mathrm{GJ} / \mathrm{ton}$ \\
\hline
\end{tabular}

Source: APEC Energy Security and Sustainable Development through Efficiency and Diversity: Economic lssues in Technology R\&D, Adoption and Transfer, ABARE, Report No. 07.12, 2007. 
and automobiles.

As noted before, Indonesia's economic structure rely much on primary industries, and in 2002, this sector accounted for about $37 \%$ of the total industrial energy consumption, while the number of consumption is projected to decline. In addition, the fuel price hike due to the removal of government subsidies for industrial use provides an incentive for industries to improve its energy efficiency.

By type of energy sources, in 2002, the percentage gasoline consumption of industrial sector is about 20\% from the total national consumption. However, the demand trend for gasoline of this sector indicates that the percentage consumption of gasoline is to decline in the future. For instance, in 2002, the consumption of gasoline by industrial is 11.62 kilolitres or equal to $21.43 \%$ from total nationwide consumption, and it decreased to $19.01 \%$ in 2005 .

Natural gas consumption is estimated to increase sharply at $4.2 \%$ per annum. The rapid increase in demand for natural gas in the last few years is due to the high demand for minerals and fertilisers industries. In addition, the demand for natural gas will continue to increase in the future following the government's regulation on energy mix, which is to encourage a shift from oil to natural gas. As a result, in the future, natural gas will replace oil as the main source of energy for this sector, and its consumption is projected to exceed oil consumption.

Meanwhile, coal is estimated to grow at around $4 \%$ per year and electricity is estimated to increase by $4.4 \%$ per year. The recent share of renewable energy in the industrial sector is very small. Biofuels and biomass are types of renewable energy that are mostly used in this sector. In the overlook period, renewable energy is projected to grow at a slow rate in the short term. However, in the long-term renewable energy is projected to grow at a higher rate following the global trend that utilizes more renewable energy for fueling the economy.

From this discussion, energy intensity in the industrial sector is projected to decline below the current level. Structural changes, energy mix with increasing share of natural gas and renewable energy, and high fuel price are the main factors that will contribute to the improvement of energy efficiency in this sector.

\section{Power Generation}

Power generation sector is the third contributor to the decreasing trend of Indonesia energy efficiency. Indonesia, power generation sector, is currently dominated by the state-owned power generation company. In 2004, Indonesia had 25 gigawatts (GW) of installed electricity generating capacity. By 2004, Indonesia produced electricity about 112.6 billion kilowatt-hours (Bkwh), and 86 percent of the electricity produced had come from conventional thermal sources such as oil, natural gas, and coal (Cogen3, 2004). The current power generators are dominated by oil based power generators. This type of power generators had consumed 6.80 thousand kilolitres of oil in 2004 and sharply increased to 9,000 kilolitres in 2005. In this context, electricity sector has also contributed to the increasing rate of national gasoline consumption which means it also contributes in increasing Indonesia energy intensity.

\section{Residential}

The residential sector is the least contributor to the decline of Indonesia's energy efficiency. Residential sector in Indonesia mostly uses renewable energy 
Table 4. Total national gasoline consumptions $2001-2005$ by sector

\begin{tabular}{llllll}
\hline Year & Residential & Transportation & Industrial & Electricity & Total \\
\hline 2001 & $8,172,429$ & $22,939,581$ & $11,091,353$ & $11,000,141$ & $53,205,505$ \\
2002 & $11,622,937$ & $26,766,910$ & $12,259,498$ & $6,548,939$ & $57,200,286$ \\
2003 & $11,074,403$ & $27,110,259$ & $11,197,083$ & $7,852,355$ & $57,236,103$ \\
2004 & $11,787,354$ & $29,520,778$ & $13,494,759$ & $6,796,916$ & $61,601,811$ \\
2005 & $11,294,676$ & $29,966,073$ & $11,795,661$ & $9,003,023$ & $62,061,438$ \\
\hline
\end{tabular}

Source : Ministry of Energy and Minerals of Indonesia (2005)

as the main sources of energy because the majority of Indonesian residents who live in the rural area are using combustible renewable energy. The rural residents use combustible renewable energy such as biomass energy as their main sources of energy for cooking. Meanwhile, the urban citizens mostly use oil and gas as their main sources of energy for automobiles, cooking, and heating, while using electricity for lighting and electronic devices. The high share of renewable energy and electricity among the energy sources is the main factor that contributes to the energy efficiency improvement in Indonesia.

Despite residential sector being the least contributor to the decline of energy efficiency, the energy demand in this sector is still growing at a low rate. The main factors that contribute to the residential energy consumption growth are income growth due to modest economic growth and the increasing number of population. From the economic point of view, higher income leads to change in the lifestyle. Residents are now using more electronic devices than before. Electronic devices such as television and refrigerator now become standard devices for most households.

Energy demand in the residential sector is expected to raise at 1.1 percent per annum -a rate which is lower compared to over the last 20 years-, which is estimated to be at 2.1 percent per annum. The switch from kerosene to natural gas is the factor that drives the lower rate of energy demand in the residential sector. The government has implemented energy mix policy by encouraging the resident to switch from kerosene to natural gas while reducing the supply of kerosene. As a result, a majority of residents living in the cities are using natural gas for cooking purposes.

The percentage gasoline consumption of residential is about $20 \%$ from the total national consumption in the year 2002, and the trend of this sector indicates that the consumption of gasoline is decreasing. In 2002, the consumption of gasoline by residential sector was 12.26 kiloliters or equal to $20.32 \%$ from total nationwide consumption, and it decreased to $18.20 \%$ in 2005 .

\section{Conclusion and recommendation}

Facing a decreasing trend of energy efficiency, the Government of Indonesia through its Ministry of Energy and Mineral Resources should take immediate action to tackle this issue, since improving energy efficiency of energy use is a key solution to improving energy security, improve industry profitability and competitiveness, and reduce the overall energy sector impacts on climate change (Taylor et al., 2007).

Furthermore, in recent years, the climate change issue should be taken into consideration by policymakers around the globe including Indonesia 
in designing its energy policy, since the impact of climate change is global. The GOI should contribute to the effort of fighting climate change. The policy in the energy sector that transform the use of fossil fuels as the main energy sources to renewable energy source would be the part of the global action in fighting climate change.

The analysis in this study verifies that adopting renewable energy is an effective method to improve Indonesia's energy efficiency. Hence, this study recommends the MEMR to further promote renewable energy as the solution for energy efficiency problem and alternative source of energy. Practically, the MEMR should promote an integrated policy by which national planning on energy efficiency improvement and renewable energy development can be put into practice. The shift to renewable energy will improve energy efficiency on one side and reduce the dependence on oil as a main energy source on the other. The policy to further promote renewable energy will be in line with government program on energy diversification, which is one of the strategic steps to reduce the dependence of oil in the future. Through energy diversification program, Indonesia is expected to be able to provide cheaper and cleaner energy.

Acknowledgements

The authors gratefully acknowledge the support from Planning and Foreign Cooperation Bureau at Ministry of Energy and Mineral Resources of the Republic of Indonesia.

\section{References}

Abulfotuh, F. (2007). Energy efficiency and renewable technologies: the way to sustainable energy future. Desalination, 209, 275-282.

Charnes, A., Cooper, W. W., Rhodes, E., (1978). Measuring the efficiency of decision-making units. European
Journal of Operation Research, 2, 429-444.

Chien, T., Hu, J. L. (2007). Renewable energy and macroeconomic efficiency of OECD and non-OECD economies. Energy Policy, 35, 3606-3615.

Domac, J., Richards, K., Risovic, S. (2005). Socio-economic drivers in implementing bioenergy projects. Biomass and Bioenergy, 28, 97106.

ESDM. (2007). Indonesian Gasoline Consumption. Ministry of Energy and Minerals of Indonesia.

Hu, J. L., Kao, C. H. (2007). Efficient energy-saving targets for OECD economies. Energy Policy, 35 (1), 373-382.

Institute for Management Development. (2008) The World Competitiveness Yearbook 2008.

Nielsen, L. J. (1993). Energy intensity trends in 31 Industrial and Developing Countries 1950 - 1988. Energy, 18 (4), 309-322.

Taylor, Robert P.; Govindarajalu, Chandrasekar; Levin, Jeremy; Meyer, Anke S.; Ward, William A.. (2008). Financing Energy Efficiency : Lessons from Brazil, China, India, and Beyond. Energy Sector Management Assistance Program (ESMAP);. Washington, DC : World Bank. https:// openknowledge.worldbank.org/ handle/10986/6349 License: CC BY 3.0 IGO

Wei, T. (2007). The impact of energy efficiency gains on output and energy use with Cobb-Douglas production function. Energy Policy, 35, 2023-2030.

Zhou, P., Ang, B. W. (2008). Linear programming models for measuring economy-wide energy efficiency performance. Energy Policy, 36, 2911- 2916. 